\title{
DOI https://doi.org/10.30525/978-9934-26-115-2-3
}

\section{АЛГОРИТМІЗАЦІЯ ПРОЦЕСУ ФОРМУВАННЯ КОМПЕТЕНТНОСТЕЙ У ЗДОБУВАЧІВ ОСВІТИ НА ЗАНЯТТЯХ МАТЕМАТИКИ}

\author{
Соловйова В. Ф. \\ викладач математики \\ Херсонський морський фаховий коледж рибной \\ промисловості \\ м. Херсон, Україна
}

Аналіз результатів 3НО з математики в останні три роки вказує на те, що рівень сформованості математичної компетентності постійно знижується. Це свідчить про низку проблем які мають місце в освіті України, що сформувалися як результат частих змін у напрямку «вектору» руху до освітніх цілей та частими змінами самої цілі. Одним 3 механізмів досягнення покращення результатів навчальної діяльності можна привести компетентнісний підхід.

Сутність компетентнісного підходу полягає в тому, щоб сформувати в учнів не тільки систему знань, умінь i навичок, але й сукупність взаємозалежних смислових орієнтацій, досвіду діяльності, необхідних для здійснення особистісно й соціально значимої продуктивної діяльності стосовно об’єктів реальної дійсності $[1,100]$.

Процес навчання - це плекання вмінь і навичок людини виконувати певний вид діяльності застосовуючи свої набуті компетентності. Як і будь-який процес, навчання підлягає використанню певних алгоритмів дій спрямованих на досягнення необхідних результатів. Головною проблемою сучасної освіти, є вміння викладача алгоритмізувати процес 
формування компетентностей учнів 3 певним позитивним результатом.

Першим і основним алгоритмом є мотивація до вивчення певної теми або предмета загалом через актуалізацію тем чи курсу, що надає усвідомлення необхідності набуття певних знань та навичок.

Другим в списку, але не менш важливим, алгоритмом $є$ здійснення зв'язку навчання з життям, а саме: поєднання вивченого матеріалу з різними видами діяльності, праці, ціннісними характеристиками для колективу та суспільства.

Третій алгоритм полягає в формуванні системи знань, отриманих через розв'язання проблемних ситуацій, узагальнення й аналіз фактичного матеріалу.

Наступні алгоритми спрямовані на формування вмінь використовувати особистий досвід та отримані знання через розв'язування ситуативних задач; проводити моніторингові дослідження i корекцію набутих навичок через виховання і самовиховання, а також формування особистої відповідальності за рівень знань і самоосвітньої діяльності.

Як зазначено в Державному стандарті базової і середньої освіти [2], до ключових компетентностей відносяться:

1. Сочуільна і громадська компетентності;

2. Полікультурна компетентність;

3. Комунікативна компетентність;

4. Інформаџійна компетентність;

5. Уміння вчитися впродовж життя;

6. Підприємницька компетентність;

7. Екологічна грамотність $і$ здорове життя.

Розглянемо всі зазначені компетентності та форми роботи на заняттях з математики. 


\section{Соціальна і громадська компетентності}

Формування соціальної і громадської компетентності відбувається під час виконання завдань, які передбачають, для здобувачів освіти, самостійний пошук розв'язку завдань тестового рівня, 3 можливістю обрання варіанту завдання чи шляху його розв'язання. Також доцільним буде використання самооцінки та взаємо оцінки учнів під час проведення контролю знань на певних етапах заняття, а саме: виконання домашньої роботи, математичних диктантів, експрес контролю. Обговорення розв'язання задач різними способами для визначення раціонального шляху розв'язання. Залучення курсантів до роботи в групах під час виконання практичних завдань, написання проектів, проведення лабораторних робіт з математики. Залучення учнів до планування та проведення позакласних заходів та предметних тижнів.

\section{Полікультурна компетентність}

Формування даної компетентності полягає в використанні інформації з історії математичних відкритів, математичних задач зазначених у художній літературі. Розв'язання задач історико-культурного та екологічного змісту. Наголошення на внеску в розвиток математики як науки, українських математиків та зарубіжних науковців. Виховання учнів на прикладі життєвого досвіду та творчого шляху відомих математиків.

\section{Комунікативна компетентність}

Формування комунікативної компетентності полягає в розвитку вміння курсантів висловлювати власну точку зору, вироблення правильної вимови математичних термінів. Під час розв'язування задач у дошки залучати учнів до пояснення своїх дій і звертати увагу на зв'язність мовлення. Застосовувати взаємо опитування та взаємоперевірку з подальшим коментуванням. Організація групової роботи. Нестандартні форми роботи на 
заняттях, таких як «Мікрофон», «Диспут», проведення нестандартних занять.

\section{Інформаційна компетентність}

Залучення пошукових систем для отримання додаткової інформації. Використання інтерактивних технологій на заняття під час пояснення (побудова графіків функцій та візуалізація розв’язку рівнянь - графічний калькулятор «GeoGebra»), відпрацювання та контролю знань (інтернет ресурси «На урок», «Всеосвіта», Liveworksheets). Використання та складання таблиць та схем, інтерактивних карт та малюнків.

\section{Уміння вчитися впродовжс жсиття}

Написання рефератів, повідомлень, тощо. Використання випереджальних завдань. Залучення до роботи в МАН. Консультування учнів 3 питань самоосвіти. Проведення інтелектуальних конкурсів, змагань, наукових конференцій.

\section{Підприємницька компетентність}

Яскравим прикладом формування підприємницької компетентності є складання бізнес планів та проектів розвитку самоврядування групи, та проведення ярмарок, вивчення статистичних даних профільного спрямування. Розв'язування задач на відсотки. Використання інтерактивних методів. Інтегровані заняття. Позакласна робота.

\section{Екологічна грамотність і здорове жсиття}

Розв'язування текстових задач пов'язані з навколишнім середовищем (рух, відсоткові обчислення чинників ризику, математична статистика тощо). Проведення фізкультхвилинок і релаксації. Забезпечення санітарно-гігієнічних норм.

\section{Література:}

1. Марущак О. M. Поняття компетентності у педагогічній діяльності у педагогічній діяльності / О. М. Марущак / /Креативна педагогика: [наук.-метод. журнал]/Академія міжнародного співробітництва 
з креативної педагогіки «Полісся».- Житомир, 2016. Вип. 11. - С. 97-108 с.

2. Державний стандарт базової i повної загальної середньої освіти: постанова Кабінету міністрів України від 23.11.2011. № 1392.

3. Компетентністна освіта: від теорії до практики. Збірка статей. - К.: Плеяди, 2005. - 120 с. - (Відкритий урок. Основна школа. Вип. 3-4). 